4. Bardy GH, Lee KL, Mark DB, et al. Amiodarone or an implantable cardioverterdefibrillator for congestive heart failure [published erratum in N Engl J Med 2005; 352:2146]. NEngl J Med 2005;352:225-37

5. Kadish A, Dyer A, Daubert JP, et al. Defibrillators in non-ischemic cardiomyopathy treatment evaluation (DEFINITE). N Engl J Med 2004;350:2I5I-8.

6. Moss AJ, Zareba W. Hall WJ at al. Multicenter Automatic Defibrillator Trial II Investigators. Prophylactic implantation of a defibrillator in patients with myocardial infarction and reduced ejection fraction. N Engl J Med 2002;346:877-83.

7. Birnie DH, Sambell C, Johansen H, et al. Use of implantable cardioverter defibrillators in Canadian and US survivors of out-of-hospital cardiac arrest. CMAJ 2007; I77:4I-6.

8. Simpson CS, Hoffmaster B, Dorian P. Downward delegation of implantable cardioverter defibrillator decision-making in a restricted-resource environment: the pitfalls of bedside rationing [review]. Can J Cardiol 2005;21:595-9.
9. Wilson S, Kadwell S, Kane C, et al. Variations in utilization of implantable cardioverter defibrillators across Canada. Can J Cardiol 2004;20(Suppl D):I47D.

Io. The Long-Term Intervention with Pravastatin in Ischaemic Disease (LIPID) Study Group. Prevention of cardiovascular events and death with pravastatin in patients with coronary heart disease and a broad range of initial cholesterol levels. $\mathrm{N} \mathrm{EnglJ}$ Med I998;339:1349-57.

Correspondence to: Dr. Christopher Simpson, Department of Cardiology, FAPC Level 3, Kingston General Hospital, 76 Stuart St., Kingston ON K7L 2V7; fax 613 548-1387; simpsonc@kgh.kari.net

\title{
Canada's health care system and the sustainability paradox
}

\author{
Irfan Dhalla MD
}

$\infty$

See related article page 54

$\mathrm{P}$ hysician leaders, ${ }^{1}$ newspaper columnists, ${ }^{2,3}$ representatives of the business community ${ }^{4}$ and even some health policy analysts ${ }^{5}$ have all expressed concerns that publicly funded health care is unsustainable. The current federal health minister has even gone so far as to say that "both the Prime Minister and I have indicated that the status quo won't be sustainable in terms of demands on our system."

Not everyone holds this view. For example, in his report on health care in Canada, ${ }^{7}$ Roy Romanow concluded that our health care system was "as sustainable as we want it to be." Despite this countervailing argument, concerns about unsustainability have provided an impetus for proposed reform. ${ }^{1}$

In this article, I will argue that Canada faces a sustainability paradox: despite ever-increasing expenditures, both in absolute dollars and as a percentage of the national income, increases in overall spending on health care in Canada are sustainable for the foreseeable future.

\section{Are increases in government spending on health care sustainable?}

One view maintains that our publicly funded health care system is unsustainable because health care expenditures are accounting for an ever-increasing share of government spending. In Ontario, for example, health care spending accounted for just over $30 \%$ of the provincial government's expenditures in $198 \mathrm{r} / 82$, but $45 \%$ in $2004 / 05$. Assuming that current trends will continue, the Ontario government has projected that the share will increase to $55 \%$ by $2025 .{ }^{8}$

One major flaw with this line of reasoning is the assump- tion that the percentage of government expenses devoted to health care depends primarily on how much governments spend on health. When measured by percentage of government expenses, health spending also depends on 2 other key factors: how much governments spend on non-health-related items (e.g., education, police services, social assistance) and how much governments collect in taxes. If a government reduces its spending on non-health-related items or cuts taxes, the percentage of expenditures devoted to health care will increase automatically.

A closer look at the Ontario data described earlier reveals that other trends are hidden amid the seemingly inexorable rise in health care spending. For example, starting in 1988 , the share of Ontario's expenditures devoted to health care actually decreased for almost io years, from $38 \%$ to just over $35 \%$. After 1997, the share began to grow, but the increase was due in large part to reductions in spending on nonhealth-related items, tax cuts and reductions in transfers from the federal government. ${ }^{8}$

Arguments that our publicly funded health care system is unsustainable because it accounts for an ever-increasing share of government funding often depend on the premise that tax rates must be fixed or continually declining. This as-

Irfan Dhalla is with the Departments of Medicine at St. Michael's Hospital and at the University of Toronto, and with Canadian Doctors for Medicare, Toronto, Ont.

Une version française de cet article est disponible à l'adresse www.cmaj.ca/cgi/content/full/I77/I/5I/DCI 


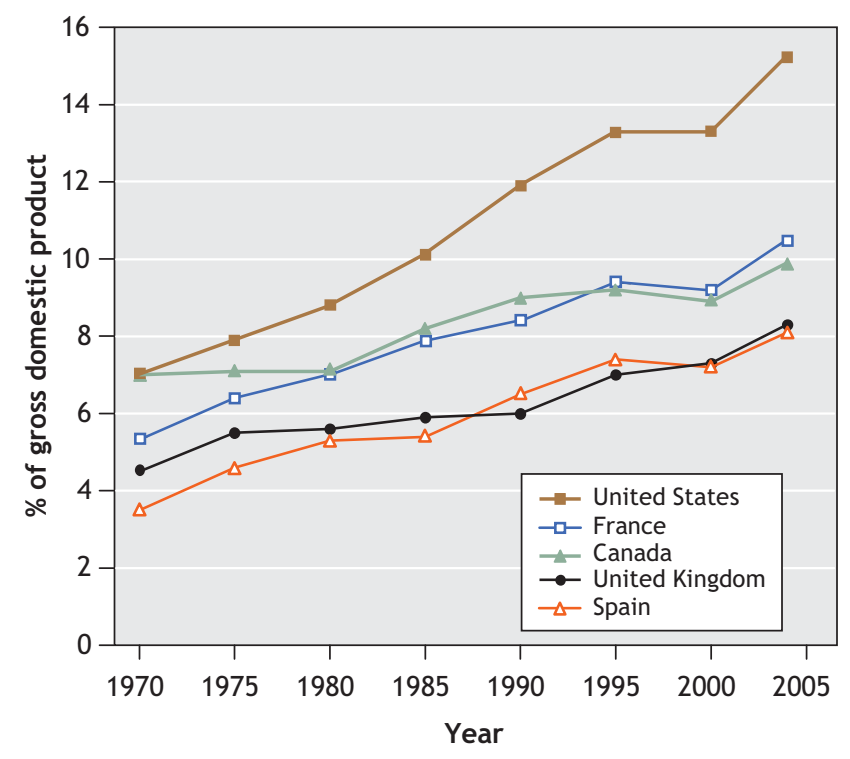

Figure 1: Health care expenditures as a percentage of the gross domestic product in 5 selected countries.

sumption, however, is open to challenge. Over the last 20 years, although the share of government tax revenue in Canada as a proportion of our gross domestic product (GDP) has remained essentially constant at 33\%, many other economically advanced countries have quietly been increasing taxes. In 1985 , members of the Organisation for Economic Cooperation and Development (OECD), a group of 30 countries "committed to democracy and the market economy," collected taxes at an average rate of $30 \%$ of their respective GDPs. By 2004, these countries were collecting taxes at an average rate of $36 \%$ of GDP. ${ }^{9}$ Although some might argue that the overall taxation level in the United States is a more appropriate benchmark for Canada than the OECD average, others would argue that comparing ourselves exclusively to the United States leads to an artificially constricted range of policy options for Canadian decision-makers. Had our taxes increased at even half the rate of those among the OECD countries, the argument that health care expenditures are unsustainable because they account for an ever-increasing share of government spending would be far less viable.

For the reasons I have described, it is problematic to assess sustainability on the basis of health care spending as a share of government expenditures. Would it be better to consider health care spending as a share of GDP instead?

\section{Is the increasing economic burden of health care sustainable?}

The prevailing view that health care spending is rising faster than both inflation and the growth of the economy is correct. However, the difference between health care spending and economic growth is smaller than many assume. Health care spending (in both the private and public sectors) accounted for $7 \%$ of Canada's GDP in 1970 , and $9.9 \%$ in $2004 .{ }^{10}$ Con-

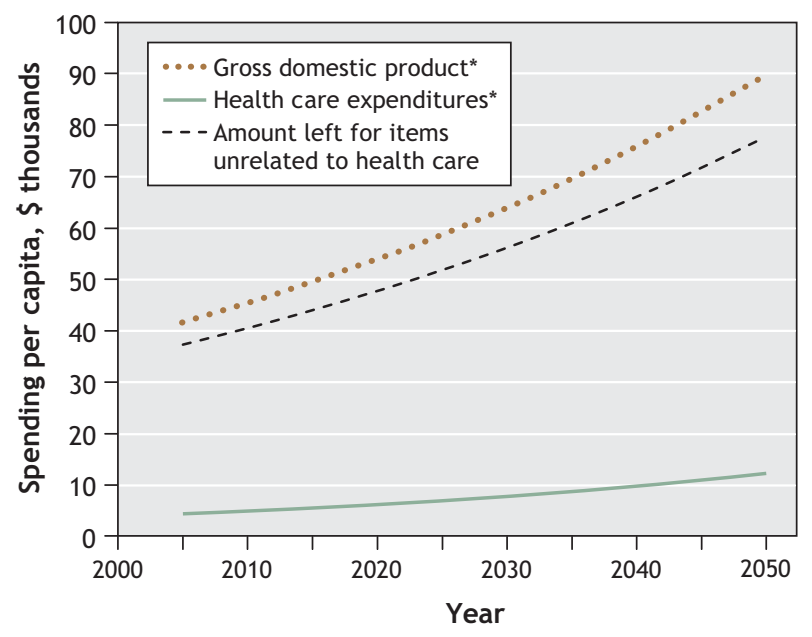

Figure 2: Long-term projections for per capita spending on health care and other non-health-related items in Canada. *The projections assume an annual growth rate per capita of $2.3 \%$ in health care spending and of $1.7 \%$ in gross domestic product.

trary to popular belief, the larger part of the increase actually occurred over the first half of the last 35 years. Similar increases have occurred in other countries, and in many cases they have been even larger than those in Canada. For example, health care spending in Spain was 3.5\% of the GDP in 1970 and $8.1 \%$ in 2004; in the United States, the corresponding numbers were $7 \%$ and $15.3 \%$ (Figure $\mathrm{I}$ ). ${ }^{10}$

Moreover, to measure health care spending as a percentage of GDP obscures an extremely important fact: over the last 35 years, the economy in all economically advanced countries has been growing. This growth has allowed us to spend more, not only on health but on a variety of other goods and services as well. In terms of sustainability, spending on health care itself is unimportant; what matters is how much we have left to spend on our other needs and desires. In other words, growth in health care spending is sustainable provided it does not reduce the average Canadian's ability to purchase nonhealth-related goods and services.

Over the last 35 years, despite the phenomenal growth in health care spending, we have still had enough left to spend ever-increasing amounts on non-health-related goods and services. How is this possible? Imagine a country where spending on health care is \$I per capita and the GDP is \$roo per capita. If, over 50 years, health care spending increases by 100 times, to $\$ 100$, and the GDP increases ro times, to $\$ 1000$, the amount of money left for non-health-related spending has still increased from $\$ 99$ to $\$ 900$. In other words, the citizens of this imaginary country would have seen their health care spending increase from $\mathrm{I} \%$ of GDP to $10 \%$ of GDP and would still have almost ro times as much money left for non-healthrelated spending. Some would call this the miracle of economic growth.

From 1992 to 2004, real per capita spending on health care (i.e., after exclusion of the effects of inflation) in Canada increased at a rate of $2.3 \%$ per year. ${ }^{10}$ During the same period, 
real per capita economic output (GDP) increased at a rate of I. $7 \%$ per year. ${ }^{11}$ If these growth rates were to continue indefinitely (and these numbers are similar to those forecasted by at least one provincial government ${ }^{8}$ ), the amount of money left for non-health-related spending would continue to increase for well over a century (Figure 2).

\section{Conclusions}

Is our health care system unsustainable? I have argued that increases in health care spending are sustainable as long as growth in non-health-related spending can still occur. From the evidence I have presented here, one can see that nonhealth-related spending can continue to increase even if health care expenditures grow at a faster rate than that of the GDP, provided the economy continues to grow over the long term.

Governments might argue that our health care system could still be unsustainable, if it were to crowd out other important government priorities, such as spending on child care or the environment. This argument would be true only if governments were incapable of increasing taxes.

An obvious and important question remains: Should health care spending continue to grow at current rates? To answer this question would require an analysis of whether we are obtaining value for the money we spend. Evidence on this point is limited; however, one recent analysis of health care spending in the United States (where costs are significantly higher than in Canada) concluded that overall increases in spending have provided "reasonable value." ${ }^{12}$ Given the limited strength of this evidence, it might be reasonable to argue that society has an interest in limiting further growth in health care expenditures. However, arguments that health care spending cannot grow at current rates are, because of the sustainability paradox, unsound.

This article has been peer reviewed.

Competing interests: None declared.

Acknowledgements: I thank Tara Kiran, David Naylor, Jeff Kwong and Gordon Guyatt for their thoughtful comments on drafts of this article.

\section{REFERENCES}

I. CMA Task Force on the Public-Private Interface. It's about access! Informing the debate on public and private health care. Ottawa: Canadian Medical Association; 2006. Available: www.cma.ca/multimedia/CMA/Content_images/Inside_Cma /Media_Release/pdf/2006/about_access_e2.pdf (accessed 2007 Mar 28).

2. Mason G. Health system, you're fired. Globe and Mail [Toronto] 2005 Nov I2;Sect A:3

3. Simpson J. Who will start a frank debate on health care? Globe and Mail [Toronto] 2004 Apr I;Sect A:I7.

4. Challenging health care system sustainability: understanding health system performance of leading countries. Ottawa: The Conference Board of Canada; 2004 Available: www.health.gov.ab.ca/resources/publications/Conference_Board2.pdf (accessed 2007 Mar 28)

5. MacKinnon JC. The arithmetic of health care. $C M A J$ 2004;171:603-4.
6. Ivison J. Clement sees 'opportunities' in health care talk. Watching Alberta closely: federal health minister says 'a lot' can be accomplished within the Canada Health Act. National Post [Toronto] 2006 Mar 2;Sect A:5.

7. Romanow RJ. Building on values: the future of health care in Canada - final report. Saskatoon: Commission on the Future of Health Care in Canada; 2002. Available: www.hc-sc.gc.ca/english/pdf/romanow/pdfs/HCC_Final_Report.pdf (accessed 2007 Mar 28).

8. Ontario Ministry of Finance. Toward 2025: assessing Ontario's long-term outlook. Toronto: The Ministry; 2005. Available: www.fin.gov.on.ca/english/economy/ltr 12005/05_ltr.pdf (accessed 2007 Mar 28).

9. Organisation for Economic Co-operation and Development. Revenue statistics 1965-2004. Paris: OECD Publishing; 2005.

Io. Organisation for Economic Co-operation and Development. OECD health data 2006: statistics and indicators for 30 countries. Paris: OECD Publishing; 2006.

II. Baldwin JR, Brown M, Maynard JP, et al. Catching up and falling behind: the performance of provincial GDP per capita from Iggo to 2003 [Economic Analysis Research Paper Series]. Ottawa: Statistics Canada; 2004. Cat no IIFoo27MIE - no 024. Available: www.statcan.ca/english/research/IIFo027MIE/IIFo027MIE2004024.pdf (accessed 2007 Mar 28).

I2. Cutler DM, Rosen AB, Vijan S. The value of medical spending in the United States, I960-2000. N Engl J Med 2006;355:920-7.

Correspondence to: Dr. Irfan Dhalla, Department of Medicine, St. Michael's Hospital, 30 Bond St., Toronto ON M5B IW8; irfan.dhalla@utoronto.ca

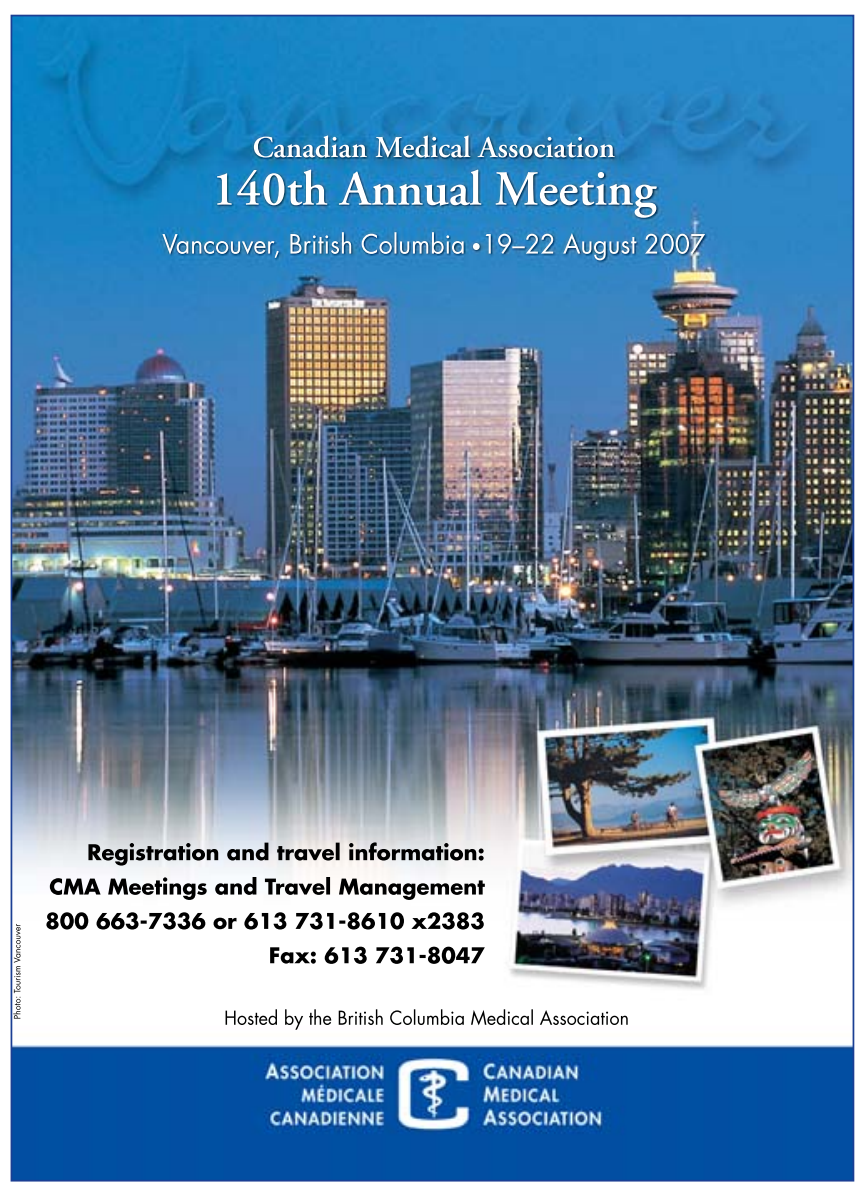

